\title{
KNOWLEDGE, ATTITUDE AND PRACTICE REGARDING ORAL HEALTH AMONG SECONDARY SCHOOL STUDENTS OF AZAD KASHMIR, PAKISTAN
}

\author{
Rashid Mehmood', Saeeda Rasheed', Mudassar ljaz'1 \\ 1Department of community medicine, AJK Medical College Muzaffarabad, Pakistan \\ Correspondence: Rashid Mehmood, Email: rashidmehmood1993@gmail.com,Contact: +92-3135232606
}

\begin{abstract}
Background: Dental carries is a major health issue experienced by $90 \%$ of school children and adults worldwide. Studies have shown that appropriate oral health education can help to cultivate healthy oral practices.

Objective: To determine knowledge, attitude and practices of the secondary school students of Azad Kashmir, regarding oral health

Methods: This cross sectional study was done from July 2013-February 2014. Data was collected by random sampling method using a pretested questionnaire.

Results: Knowledge level of about $95 \%$ students ( $47 \%$ male \& $48 \%$ females) was satisfactory according to recorded response. About $88 \%$ students ( $43 \%$ male \& $45 \%$ females) were well aware about fluoride. A percentage of $41.7 \%$ clean their teeth once a day, $32.3 \%$ twice a day, $17.7 \%$ three times a day and $8 \%$ more than three times a day. $63 \%$ used brush and tooth paste, $37 \%$ used only brush as oral hygiene tool. Tooth paste + brush were most common tools of oral hygiene. Dental visits were low. Consumption of sweet food was frequent.

Conclusion: The oral health attitude and practice among the students in Azad Kashmir is still below the satisfactory level.
\end{abstract}

Keywords: Oral health education, kashmir, dental carries

Introduction

About $90 \%$ of school children worldwide and most adults have experienced caries, with the disease being most prevalent in Asian and Latin American countries. For an improvement in oral health status, environmental risk factors such as oral hygiene can play an important role in prevention of dental caries (1).

Strong knowledge of oral health demonstrates better oral care practice. The change to healthy attitude and practice can be occurred by given adequate information, motivation and practice of the measures to the subjects (2).

Similarly for those with more positive attitude towards oral health are influenced by better knowledge in taking care of their teeth. Studies have shown that appropriate oral health education can help to cultivate healthy oral health practice (3).

In order to create such health education, the assessment of knowledge, attitude and practice is essential (4).

The aim of this study was to assess the level of knowledge and attitude towards oral health among the secondary students in Azad Kashmir and to evaluate the practice of oral hygiene among the secondary school students. Secondary schools students were interviewed using a pretested questionnaire (5).

Methodology

This was a cross-sectional study using simple convenient method conducted from July 2013 to February 2014 in Secondary schools of Azad Kashmir. The target population consists of secondary school students. The present KAP study enrolled 384 respondents representing target population. Total 1000 structured pretested questionnaires translated in local language (Urdu) were distributed. We received 384 completely filled feed-backs out of 1000 . The study assessed knowledge, attitude and practice regarding oral health. Students of lower and higher grades were excluded from study. Participants were interviewed using a pretested questionnaire. Before it was used, the questionnaire was pretested in the pilot study. The questionnaire consisted of four parts comprising 19 questions and information collected through questionnaire included (1) General information on respondents including age, gender etc. (2) knowledge regarding oral hygiene (3) attitude and (4) practice regarding oral hygiene. Informed written consent was taken from all respondents prior to data collection. They were assured for maintaining their privileges and 
anonymity. Data collected was analyzed statistically using SPSS-software (version 21). Original patient's data were filed and locked by principal author.

\section{Results}

A total of 1000 questionnaire were distributed among randomly selected secondary school students of Azad Kashmir. Only 400 questionnaires were returned and among them 16 were incompletely filled for more than 5 questions so they were discarded. 384 participants with mean age of 15 years (min 10-max 20 years) were analyzed. Among them n189 (49.2\%) were males and n195 (50.8\%) were females.

For knowledge of oral health, 96 to $99 \%$ students were well aware about causes of dental carries (consumption of too much sweet), meaning of dental plaque and its effect on dental health. About $97 \%$ had the awareness of benefits of regular brushing. Question number 8, 9 and 10 were wrongly answered by $8-13 \%$ of students. Approximately $11 \%$ of the respondents did not know that soft drinks are harmful for teeth, whereas for fluoride, $12 \%$ did not knew that it strengthens the teeth, $8 \%$ said that dental health has no relation with general health of body. There is no significant difference of knowledge level between male and female students. Details of the knowledge score is presented in Table 1.

Table 1: Frequency distribution of knowledge scores as correct and wrong answers

\begin{tabular}{|l|l|l|l|l|}
\hline Question & $\begin{array}{l}\text { Correct } \\
\text { (n) }\end{array}$ & Correct (\%) & $\begin{array}{l}\text { Wrong } \\
\text { (n) }\end{array}$ & Wrong (\%) \\
\hline $\begin{array}{l}\text { Consuming too much sweet food } \\
\text { causes tooth decay/dental caries. }\end{array}$ & 379 & $\begin{array}{l}98.7(\mathrm{M}=49, \mathrm{~F} \\
=49.7)\end{array}$ & 5 & $\begin{array}{l}1.3(\mathrm{M}=0.3, \mathrm{~F} \\
=1.0)\end{array}$ \\
\hline Gum bleeding means inflamed gum. & 370 & $\begin{array}{l}96.4(\mathrm{M}=48.7, \\
\mathrm{F}=47.7)\end{array}$ & 14 & $\begin{array}{l}3.6(\mathrm{M}=0.5, \mathrm{~F} \\
=3.1)\end{array}$ \\
\hline $\begin{array}{l}\text { Regular brushing of teeth can protect } \\
\text { oneself from gum bleeding. }\end{array}$ & 370 & $\begin{array}{l}96.4(\mathrm{M}=46.9, \\
\mathrm{F}=49.5)\end{array}$ & 14 & $\begin{array}{l}3.6(\mathrm{M}=2.3, \mathrm{~F} \\
=1.3)\end{array}$ \\
\hline $\begin{array}{l}\text { Dental plaque means soft debris on } \\
\text { teeth. }\end{array}$ & 375 & $\begin{array}{l}97.7(\mathrm{M}=47.4, \\
\mathrm{F}=50.3)\end{array}$ & 9 & $\begin{array}{l}2.3(\mathrm{M}=1.8, \mathrm{~F} \\
=0.5)\end{array}$ \\
\hline $\begin{array}{l}\text { Dental plaque can lead to dental } \\
\text { caries. }\end{array}$ & 374 & $\begin{array}{l}97.4(\mathrm{M}=46.9, \\
\mathrm{F}=50.5)\end{array}$ & 10 & $\begin{array}{l}2.6(\mathrm{M}=2.3, \mathrm{~F} \\
=0.3)\end{array}$ \\
\hline $\begin{array}{l}\text { Carious or decayed teeth can affect } \\
\text { teeth appearance. }\end{array}$ & 375 & $\begin{array}{l}97.7(\mathrm{M}=47.7, \\
\mathrm{F}=50.0)\end{array}$ & 9 & $\begin{array}{l}2.3(\mathrm{M}=1.5, \mathrm{~F} \\
=0.8)\end{array}$ \\
\hline Sweets affect the teeth adversely. & 379 & $\begin{array}{l}98.7(\mathrm{M}=48.2, \\
\mathrm{F}=50.5)\end{array}$ & 5 & $\begin{array}{l}1.3(\mathrm{M}=1.0, \mathrm{~F} \\
=0.3)\end{array}$ \\
\hline $\begin{array}{l}\text { Fizzy drinks affect the teeth adversely. } \\
\text { to oral health and dental diseases. }\end{array}$ & 342 & $\begin{array}{l}89.1(\mathrm{M}=43.5, \\
\mathrm{F}=45.6)\end{array}$ & 42 & $\begin{array}{l}10.9(\mathrm{M}=5.7, \\
\mathrm{F}=5.2)\end{array}$ \\
\hline Using fluoride strengthens the teeth. & 339 & $\begin{array}{l}88.3(\mathrm{M}=43.8, \\
\mathrm{F}=44.5)\end{array}$ & 45 & $\begin{array}{l}11.7(\mathrm{M}=5.5, \\
\mathrm{F}=6.3)\end{array}$ \\
\hline $\begin{array}{l}\text { General body health has a relationship } \\
\mathrm{F}=47.7)\end{array}$ & 353 & $\begin{array}{l}8.1(\mathrm{M}=4.9, \mathrm{~F} \\
=3.2)\end{array}$ \\
\hline
\end{tabular}

Table 2 presents the attitude towards oral health according to gender. About $51.6 \% \%(n=198)$ of the respondents (26\% female; $25.5 \%$ male) reported that they would only visit the dentist when they have dental pain. About $3.1 \%(n=12)$ students $(1.6 \%$ male and $1.6 \%$ female) regularly visited the dentist and $35 \%$ students(male $17.2 \%$ and female $18.2 \%$ ) have never visited the dentist in their life. There was no significant difference of the frequency of dental visit by gender ( $p$ $>0.717$ ).

Table 2: Attitude of the respondents towards oral health.

\begin{tabular}{|c|c|c|c|c|c|}
\hline Variable & Response & $\begin{array}{l}\text { Total: } \\
\text { n(\%) }\end{array}$ & Male[n(\%)] & Female $[n(\%)]$ & $p$ value \\
\hline \multirow[t]{4}{*}{$\begin{array}{l}\text { Frequency } \\
\text { of dental } \\
\text { visits }\end{array}$} & $\begin{array}{l}\text { Regularly } \\
\text { (every 6-12 } \\
\text { months) }\end{array}$ & $12(3.1)$ & $6(1.6)$ & $6(1.6)$ & \multirow[t]{4}{*}{0.717} \\
\hline & Occasionally & $36(9.4)$ & $15(3.9)$ & $21(5.5)$ & \\
\hline & $\begin{array}{l}\text { When I have } \\
\text { dental pain }\end{array}$ & $198(51.6)$ & $100(16)$ & $98(25.5)$ & \\
\hline & Never & $138(35.9)$ & $68(17.7)$ & $70(18.2)$ & \\
\hline \multirow{5}{*}{$\begin{array}{l}\text { History of } \\
\text { last dental } \\
\text { visit }\end{array}$} & $\begin{array}{l}\text { Less than } 6 \\
\text { months ago }\end{array}$ & $47(12.2)$ & $19(4.9)$ & $28(7.3)$ & \multirow[t]{5}{*}{0.539} \\
\hline & $\begin{array}{l}\text { Last 6-12 } \\
\text { months }\end{array}$ & $28(7.3)$ & $14(3.6)$ & $14(3.6)$ & \\
\hline & $\begin{array}{l}\text { Last 1-5 } \\
\text { years }\end{array}$ & $58(15.1)$ & $28(7.3)$ & $30(7.8)$ & \\
\hline & $\begin{array}{l}\text { Greater than } \\
5 \text { years }\end{array}$ & $113(29.4)$ & $63(16.4)$ & $50(13)$ & \\
\hline & $\begin{array}{l}\text { never visited } \\
\text { a dentist }\end{array}$ & $138(35.9)$ & $68(17.7)$ & $70(18.2)$ & \\
\hline
\end{tabular}

Table 3 shows the practices for oral health according to gender. About $12.2 \% \%(n=47)$ of the respondents $(4.9 \%$ male; $7.3 \%$ female) had their last visit to the dentist less than six months ago. There were $29.4 \%$ (13\% female; $16.4 \%$ male) who last visited the dentist more than five years ago. There was no significant difference of the frequency of last dental visit between genders $(p>$ 0.539 ). About $32.3 \%$ of the respondents reported brushing their teeth at least twice a day. Female students $(15.1 \%)$ brush their teeth more than twice a day as compared to male students $(9.9 \%)$. However, female students $(29.2 \%)$ have a higher frequency (2-4 times a day) of consumption of sweet food daily compared to male students $(9.9 \%)$. 
Table 3: Practices of the respondents regarding oral health.

\begin{tabular}{|c|c|c|c|c|c|}
\hline Variable & Response & $\begin{array}{l}\text { Total: } n \\
(\%)\end{array}$ & $\begin{array}{l}\text { Male [n } \\
(\%)]\end{array}$ & $\begin{array}{l}\text { Female [n } \\
(\%)]\end{array}$ & $p$ value \\
\hline \multirow{4}{*}{$\begin{array}{l}\text { Frequency } \\
\text { of tooth } \\
\text { brushing }\end{array}$} & $\begin{array}{l}\text { No } \\
\text { brushing }\end{array}$ & $4(1)$ & $1(0.3)$ & $3(0.8)$ & \multirow[t]{4}{*}{$\mathrm{p}=0.64$} \\
\hline & Once a day & $160(41.7)$ & $83(21.6)$ & $77(20.1)$ & \\
\hline & $\begin{array}{l}\text { Twice a } \\
\text { day }\end{array}$ & $124(32.3)$ & $67(17.4)$ & $57(14.8)$ & \\
\hline & $\begin{array}{l}\text { More than } \\
\text { twice a day }\end{array}$ & $96(25)$ & $38(9.9)$ & $58(15.1)$ & \\
\hline \multirow{4}{*}{$\begin{array}{l}\text { Time spent } \\
\text { for } \\
\text { brushing }\end{array}$} & $\begin{array}{l}\text { Less than } 1 \\
\text { minute }\end{array}$ & $26(6.8)$ & $14(3.6)$ & $12(3.1)$ & \multirow[t]{4}{*}{$\mathrm{p}=0.147$} \\
\hline & 1 minute & $39(10.2)$ & $23(6.0)$ & $16(4.2)$ & \\
\hline & 2 minutes & $98(25.5)$ & $50(13.0)$ & $48(12.5)$ & \\
\hline & $\begin{array}{l}\text { More than } \\
2 \text { minutes }\end{array}$ & $221(57.6)$ & $102(26.6)$ & $119(31.0)$ & \\
\hline \multirow{4}{*}{$\begin{array}{l}\text { Frequency } \\
\text { of eating } \\
\text { sweet food } \\
\text { per day }\end{array}$} & $\begin{array}{l}\text { Less than } 1 \\
\text { time }\end{array}$ & $90(23.4)$ & $43(11.2)$ & $47(12.2)$ & \multirow[t]{4}{*}{$\mathrm{p}=0.828$} \\
\hline & 2-4 times & $227(59.1)$ & $115(9.9)$ & $112(29.2)$ & \\
\hline & $4-6$ times & $26(6.3)$ & $11(2.9)$ & $13(3.4)$ & \\
\hline & $\begin{array}{l}\text { More than } \\
6 \text { times }\end{array}$ & $43(11.2)$ & $20(5.2)$ & $23(6)$ & \\
\hline \multirow{4}{*}{$\begin{array}{l}\text { Frequency } \\
\text { of taking } \\
\text { soft drinks }\end{array}$} & $\begin{array}{l}1 \text { time/ } \\
\text { week }\end{array}$ & $104(27.1)$ & $67(17.4)$ & $37(9.6)$ & \multirow[t]{4}{*}{$\mathrm{p}=0.240$} \\
\hline & $\begin{array}{l}2 \text { times / } \\
\text { week }\end{array}$ & $47(12.2)$ & $26(6.8)$ & $21(5.5)$ & \\
\hline & $\begin{array}{l}3-5 \text { times / } \\
\text { week }\end{array}$ & $45(11.7)$ & $15(3.9)$ & $30(7.8)$ & \\
\hline & Everyday & $188(49)$ & $81(21.1)$ & $107(27.9)$ & \\
\hline
\end{tabular}

\section{Discussion}

Only two questions on effect of fizzy drinks and fluoride on dental health (Table 2; Questions 8 and 9) were answered correctly by less than $90 \%$ of participants. Question about relation of oral and body health was answered correctly by $92 \%$ of students (Table 2; Question 10). Rest of questions (1-9) regarding knowledge of oral hygiene were answered correctly by about $97 \%$ of students. The lack of knowledge in the dental health could reflect the dental health education, which is most likely was limited to certain level of understanding. There was no significant difference of the knowledge level between genders. This may be because both genders are equally educated. However a study in India reported that reported that boys had better knowledge than girls (6).

Majority $(51.2 \%)$ of the students only visited their dentist when they had dental pain. Approximately $(3.1 \%)$ of the students had regular dental visit every 6 to 12 months. This could be due to lack of school oral health programs. The frequency of dental visit remains very low as compared to half $(50 \%)$ of the 1351 second-year secondary school students in Canada used dental services once in every six months (7).

This may be due to the lack of awareness regarding visiting dentists among these students that caused the frequency of visit low. Low dental visits may probably be due to low awareness of importance of oral health, thus affects the student's health seeking behaviour (8).

This study also showed that $15 \%$ of the students did visit their dentists in the last 1-5 years, which is much lower than $95-96 \%$ reported in Finland (9).

Family and friends seems to play a minor role in advising a dental visit. The main reason that hampered a dental visit was fear of the dental needle. Early oral education in children had a positive influence on dental anxiety, improving the long term dental follow-up (10-11).

A study in California among the pre-school children showed that parents played a major role in influencing their children's oral health and access to care. These findings could be explained by the fact that the respondents in this study are teenagers who try to achieve independence and establish their own identity without family and friends interference. The role of dentists in promoting and disseminating the knowledge of oral disease prevention is essential. However, with the limited number of dentists serving the patients, the amount of time dentists can spend with each of the patient is compromised. Therefore, the role of educating oral health should not totally on dentists alone. Delay in seeking dental care could be attributed to other factors like lack of economic resources and accessibility of dental services (12).

The study showed that $32.3 \%$ of the students brushed their teeth at least twice a day. There were $25 \%$ of the students who brushed their teeth more than twice per day. Girls were found to brush their teeth more frequently, and spent longer time during tooth brushing as compared to boys, supported by other studies (1318).

Tooth brush and tooth paste were the most commonly used oral hygiene aids, as that reported elsewhere (19).

Female students had more sugar intake than the male students from the consumption of sweet food and soft drinks. Studies had shown that girls usually have greater preference for sweet foods while boys will opt for higher fat and salt content fast-foods and snacks (20).

Other than sweets, carbonated drinks was reported to be the most favourable among the respondents where majority claimed they drink carbonated drinks and $49 \%$ have at least once per day. The availability of the sweet food, snacks and carbonated drinks within and outside the compound of the school had facilitated the purchasing of the items among the students. Students seem to be more attracted by the taste and appearance of the food than its nutritional value. Since there was no 
dental records of the school students, this study was not able to compare the students' knowledge, attitude and practice of oral knowledge with their oral health status. No such type of study was done before in Azad Kashmir and Pakistan so no data was available to compare with this study.

\section{Conclusion}

In conclusion, the oral health attitude and practice among the students in Azad Kashmir is still below the satisfactory level. The findings of this study suggest that awareness on the importance of oral health needs to be enhanced among the secondary school students in Azad Kashmir. There is a need to decrease dependency on oral health personnel, and encourage students to take responsibility for their own oral health. The schools may serve as the best platform for promotion of oral health care among teenagers. The oral health education programs should be intensified to promote oral healthcare a lifelong practice. The incorporation of oral health education activities into the school's curriculum should be done, but more efforts in the form of educational materials, health promotion activities need to be carried out. Undoubtedly, the support from the parents and teachers in various ways is essential. The school health policies should be revised with the introduction of healthy eating behaviour that limits sweet foods and drinks in the school premises. Healthy foods must be made available in the school canteens, while the canteens should be prohibited from selling food and drinks that contain very high sugar levels. Although parents play a role of influence the eating behaviour of their children, a more effective idea would be empowering the children to make healthy food choices.

\section{Acknowledgements}

My Special thanks to Chief co-ordinator Prof. Dr. Iqbal Khan and Prof. Dr. Anwar ul Haque.

\section{References}

1. Petersen PE, Bourgeois D, Ogawa $\mathrm{H}$, Estupinan-Day S Ndiaye C. The global burden of oral diseases and risks to oral health. Bull World Health Organ. 2005;83(9): 661-69.

2. Smyth E, Caamano F, Fernández-Riveiro P. Oral health knowledge, attitudes and practice in 12year-old schoolchildren. Med Oral Patol Oral Cir Bucal. 2007;12(8): E614-E20.

3. Ab-Murat N, Watt RG. Chief dentists' perceived strengths and weaknesses of oral health promotion activities in Malaysia. Annal Dent Univ Malaya. 2006;13: 1-5.

4. Al-Omiri MK, Al-Wahadni AM, Saeed KN. Oral health attitudes, knowledge, and behavior among school children in North Jordan. J Dent Educ. 2006;70(2): 179-187.

5. Stenberg P, Håkansson J, Akerman S. Attitudes to dental health and care among 20 to 25 -yearold Swedes: results from a questionnaire. Acta Odontol Scand. 2000;58(3): 102-106

6. Joshi N, Rajesh R and Sunitha M. Prevalence of dental caries among school children in Kulasekharam village: A correlated prevalence survey. 2005;23(3):138-140.

7. Scott G, Brodeur JM, Olivier M, Benigeri M. Parental factors associated with regular use of dental services by second-year secondary school students in Quebec. J Can Dent Assoc. 2002; 68(10): 604-608.

8. Biesbrock A, Corby PM, Bartizek R, Corby AL, Coelho M, Costa S, Bretz WA and Bretz WA. Assessment of treatment responses to dental flossing in twins. J Periodontol. 2006;77(8): 1386-1391.

9. Honkala S, Honkala E, Rimpelä A, Vikat A. Oral hygiene instructions and dietary sugar advice received by adolescents in 1989 and 1997. Community Dent Oral Epidemiol. 2002;30(2): 124-132.

10. Nicolas E, Collado V, Faulks D, Bullier B, Hennequin M. A national cross-sectional survey of dental anxiety in the French adult population. BMC Oral Health, 2007;7:12

11. Taani DQ. Dental attendance and anxiety among public and private school children in Jordan. Int Dent J. 2002 Feb;52(1): 25-29.

12. Barker JC, Horton SB. An ethnographic study of Latino preschool children's oral health in rural California: Intersections among family, community, provider and regulatory sectors. BMC Oral Health. 2008;8:8

13. Rise J, Haugejorden $O$, Wold B, Aarö LE. Distribution of dental health behaviors in Nordic school children. Community Dent Oral Epidemiol.1991;19(1): 9-13.

14. Kuusela S, Honkala E, Rimpelä A, Karvonen S, Rimpelä M. Trends in toothbrushing frequency among Finnish adolescents between 1977 1995. Community dental health. 1997 Jun;14(2):84-8.

15. Honkala S, Honkala E, Rimpelä A, Vikat A. Oral hygiene instructions and dietary sugar advice received by adolescents in 1989 and 1997. Community Dent Oral Epidemiol, 2002;30(2): 124-132.

16. Al-Sadhan SA. Oral health practices and dietary habits of intermediate school children in Riyadh, Saudi Arabia. Saudi Dental J. 2003;15(2): 81-87.

17. Lin HC, Wong MC, Wang ZJ and Lo EC. Oral health knowledge, attitudes, and practices of Chinese adults. J Dent Res, 2001;80(5): 14661470.

18. Al-Ansari JM, Al-Jairan LY and Gillespie GM. Dietary habits of the primary to secondary school population and implications for oral health. J Allied Health.2006;35(2): 75-80.

19. Russel BA, Horowitz AM and Frazier PJ. Schoolbased preventive regiments and oral health knowledge and practices of sixth graders. J 
Public Health Dent.1989; 49(4): 192-200.

20. Ogarah-Pratap, B. Dietary habits of Mauritian school adolescents. Nutr Food Sci. 2007;37(6): 442-451. 